\title{
Shuttle Service
}

National Cancer Institute

\section{Source}

National Cancer Institute. Shuttle Service. NCI Thesaurus. Code C141288.

A transportation service that makes frequent trips between two places. 